\title{
A new species of Mesocyclops (Copepoda, Cyclopoida, Cyclopidae) from Southeastern Mexico
}

\author{
Martha A. GUTIÉRREZ-AGUIRRE and Eduardo SUÁREZ-MORALES* \\ El Colegio de la Frontera Sur (ECOSUR), A.P. 424, Chetumal, Quintana Roo 77000, Mexico \\ *e-mail corresponding author: esuarez@ecosur-qroo.mx
}

\begin{abstract}
The taxonomical status of several neotropical species of Mesocyclops is still uncertain. Furthermore, several new species with a restricted distributional range have been described recently in this region. From littoral zooplankton samples collected in the lowlands of the State of Tabasco, Southeastern Mexico, male and female specimens of a previously unknown species of Mesocyclops were found. This new species is described herein based on both sexes and following the upgraded standards set for the taxonomic study of this genus, including SEM analysis. The new species differs from its congeners by a combination of several characters: the unique shape of the antennular hyaline membrane, the ornamentation of both maxillule and maxilla, the ornamentation of the fourth swimming leg, the shape and structure of the genital receptacle, and the ornamentation of the furcal rami. It is most closely related to other neotropical species such as M. meridianus Kiefer, 1926 and M. pseudomeridianus Defaye \& Dussart, 1989. This is the eleventh species of Mesocyclops known from Mexico, and also the third new species described upon Mexican material. Due to the affinity of the Tabasco fauna with the Caribbean and the South American copepod faunas, the new species is expected to have a relatively wide geographical distribution in the neotropical region.
\end{abstract}

Key words: Cyclopoida, description, Mesocyclops, Mexico, Neotropical

\section{INTRODUCTION}

The genus Mesocyclops G. O. Sars 1914, includes freshwater copepods widely distributed in the tropical and subtropical regions of the world (Van de Velde 1984). Up to $75 \%$ of the nearly 65 species currently known have been described during the last two decades (Van de Velde 1984; van de Velde 1987; Dussart \& Fernando 1988: Fiers et al. 1996; Holynska 2000b). The taxonomical status of several species described and distributed in the Neotropical region is still uncertain mainly because the morphological information about these taxa is insufficient according to the new taxonomic standards which are expected to be useful to reliably separate these species (Fiers et al. 1996; Gutiérrez-Aguirre \& Suárez-Morales 2001a). This upgraded analysis has been successfully used to characterize the Australasian species of Mesocyclops (Holynska 2000b).

The taxonomic knowledge about the genus in Mexico is still largely incomplete, this is particularly true for the tropical lowlands of the Southeastern part of the country. Suárez-Morales \& Reid (1998) published the most recent faunistic account of the Mexican freshwater copepods. In this work, they recognized as valid the records of only 7 species of Mesocyclops in Mexico; however, they stated that the local and regional lists were expected to grow with additional surveys in the tropical areas. Agreeing with this idea, a single field expedition to survey the zooplankton fauna of the lowlands in the State of Tabasco, Southeast Mexico (Gutiérrez-Aguirre \& Suárez-Morales 2001b), yielded sev- eral new records of species of Mesocyclops in Mexico: M. brasilianus Kiefer, 1933, M. thermocyclopoides Harada, 1931, and M. pescei (Pesce 1985). Furthermore, after a detailed reexamination of the specimens identified therein as M. meridianus Kiefer, 1926, we concluded that these copepods represent a new species, which is fully described and depicted herein.

\section{MATERIAL AND METHODS}

Zooplankton samples were collected on January $1^{\text {st }}$, 1998 and January $31^{\text {st }}, 1999$ during a biological survey of several freshwater environments in the state of Tabasco, Southeastern Mexico. Samples were obtained using a standard plankton net with a $0.05 \mathrm{~mm}$ mesh, by performing near-shore plankton trawls. The material was fixed in $4 \%$ formalin, and then processed for identification. Copepods were tranferred to $70 \%$ ethanol for long-term preservation. The organisms were dissected with tungstene needles and mounted in glycerine for taxonomic analysis. The appendages were illustrated with the aid of a camera lucida. Some specimens were prepared for SEM (Scanning Electron Microscopy) to allow the observation of the smallest structures. The type specimens were deposited in the Collection of Zooplankton of El Colegio de la Frontera Sur, Chetumal, Mexico (ECO-CHZ), and in the collection of Copepoda of the Muséum National d'Histoire Naturelle (MNHN), Paris. The Tabasco specimens were compared with the morphologically closest species: Mesocyclops pseudomeridianus Defaye \& Dussart, 1989; M. meridianus Kiefer, 1926; M. annulatus Wierzejskii, 1892. 
Two sites were positive for the new species of Mesocyclops, a pond at $\mathrm{km} 45$ of Jonuta-Villahermosa highway, and Lechugal lagoon. The environmental parameters at the time of collection in the first site were: depth $0.62 \mathrm{~m}$, Secchi transparency $0.41 \mathrm{~m}$, water temperature $25.7{ }^{\circ} \mathrm{C}$, pH 6.15 , Oxygen $6.4 \mathrm{mg} \mathrm{l}^{-1}$. In Lechugal lagoon the corresponding data are: depth 0.80 $\mathrm{m}$, Secchi transparency $0.80 \mathrm{~m}$, water temperature 31.2 ${ }^{\circ} \mathrm{C}, \mathrm{pH} 7$, Oxygen $1.5 \mathrm{mg} \mathrm{l}^{-1}$. The specimens were collected in sites where aquatic lily was abundant.

\section{RESULTS}

\subsection{Mesocyclops evadomingoi Gutiérrez-Aguirre n. sp.} (Pls 1-9)

Material examined. Holotype: 1 dissected adult female mounted on glycerine in semipermanent slide. Pond at $\mathrm{km} 45$ of Jonuta-Villahermosa highway, Tabasco, Mexico (17 $\left.58^{\prime} 44^{\prime \prime} \mathrm{N}, 92^{\circ} 14^{\prime} 11^{\prime \prime} \mathrm{W}\right)$, collected January 1, 1998, deposited in the Zooplankton Collection of El Colegio de la Frontera Sur, Unidad Chetumal, catalog number ECOCH-Z-01157. Allotype: 1 dissected adult male, mounted on glycerine semipermanent slide, same locality and date, deposited in the Zooplankton Collection of El Colegio de la Frontera Sur, Unidad Chetumal, catalog number ECOCH-Z-01158. Paratypes: one dissected adult female, mounted on glycerine in semipermanent slide. Lechugal lagoon, Tabasco, Mexico $\left(17^{\circ} 45^{\prime} 10^{\prime \prime} \mathrm{N}, 91^{\circ} 31^{\prime} 19^{\prime \prime} \mathrm{W}\right)$, collected January 31, 1999, ECOCH-Z-01159. One undissected adult female, ethanol-preserved, same locality and date, ECOCH-Z01160. Three adult males and three adult females, ethanol-preserved, undissected. Pond at $\mathrm{km} 45$ of JonutaVillahermosa highway, Tabasco, Mexico, collected January $1^{\text {st }}, 1998$, MNHN-Cop1915. Five adult females, and five adult males, ethanol-preserved, undissected, same locality, ECOCH-Z-01161.

Mesocyclops pseudomeridianus Defaye \& Dussart, 1989. Holotype, one dissected adult female, labelled Sud Amerique Guyana GUYANE (Mare a lentilles d'eau, Riziere de Mana). Collected October 21, 1985, by B. Dussart, deposited in the Museum National d'Histoire Naturelle, Paris, catalog number: MNHN Cop708. Mesocyclops meridianus Kiefer, 1926. Two adult females from Barra Bonita Reservoir, São Paulo, Brazil, collected between 1997 and 1999 by Marcos da Silva. Mesocyclops annulatus Wierzejskii, 1892. One adult female from Adrogué, Buenos Aires, Argentine, collected November 10, 1895, deposited in the Museum National d'Histoire Naturelle, Paris, catalog number MNHN Cop864.

Etymology. The new species epithet is formed by linking the names of the first author (MG-A) parents (Eva and Domingo), to whom it is dedicated.

Diagnoses: Female with 17-segmented antennule, hyaline membrane on segment XVII relatively narrow, without notches, straight, lightly serrated. Three groups of spines on frontal and caudal surfaces of antennal basis. Mandible without spines next to palp insertion. Caudal surface of maxillule ornamented with tiny spines. Caudal surface of maxilla with hair-like setae plus tiny spines on coxa. Fifth pediger ornamented with spines plus hair-like setae ventrally. Anterior margin of seminal receptacle deeply convex. Furcal rami with hair-like setae and scales on internal margin and ventral surface. Female and male with cuticular pits on dorsal surface of body, cephalic appendages, and genital somite. Caudal surface of coxa of fourth leg with 4 groups of spines in both sexes (two near external margin, one on distal-internal corner, one on proximal margin). Fifth leg bi-segmented, proximal segment with 1 seta, distal segment with one distal seta plus medial spine in both sexes. Male antennules 16-segmented, fifth pediger with hair-like setae on dorsal surface, furcal rami with scales on ventral and dorsal surfaces.

\subsubsection{Description of female}

Total body length $=1.10 \pm 0.06 \mathrm{~mm}(\mathrm{n}=8)$ from top of cephalothorax to furcal rami. Cephalothorax moderately expanded, mainly at first and second somites, cephalotorax length $=0.67 \pm 0.05 \mathrm{~mm}(\mathrm{n}=8)$ representing $60 \%$ of total body length. Abdomen relatively elongated (length $=0.42 \pm 0.04 \mathrm{~mm} ; \mathrm{n}=8$ ). Cuticular pits on dorsal surface visible mainly on external margin of each thoracic and genital somites. Antennules reaching posteriorly anterior margin of third somite (Pl. 1, Fig. 1).

Antennule. 17-segmented; armament per segment as follows ( $\mathrm{s}=\mathrm{seta}, \mathrm{ae}=$ aesthetasc): $8 \mathrm{~s}, 4 \mathrm{~s}, 2 \mathrm{~s}, 6 \mathrm{~s}, 3 \mathrm{~s}, 1 \mathrm{~s}+$ $1 \mathrm{ae}, 2 \mathrm{~s}, 1 \mathrm{~s}, 1 \mathrm{~s}, 0,1 \mathrm{~s}, 1 \mathrm{~s}+1 \mathrm{ae}, 0,1 \mathrm{~s}, 2 \mathrm{~s}, 2 \mathrm{~s}, 6 \mathrm{~s}+1 \mathrm{ae}$. Row of spines on first segment, internal surface (Pl. 1, Fig. 2). Rows of pits on external surfaces of antennular segments I, II, and IV (Pl. 1, Fig. 3). Length ratio of two distalmost segments XVI/XVII $=0.84$. Hyaline membrane on segment XVI and XVII serrate, without notches (Pl. 1, Fig. 4). Length ratio of seta/aesthetasc on segment XII $=3.9$.

Antenna. Coxa (no setae), basis (2 setae + exopod), and 3 -segmented endopod (1, 7, and 6 setae on each segment) (Pl. 1, Fig. 5). Frontal surface of basis with longitudinal group $\left(\alpha^{\prime}\right)$ of acute spines, a proximal group $(\alpha)$ of long spines, and 1 group of spines next to insertion of exopod seta (Pl. 2, Fig. 1). Basis caudal surface pattern: longitudinal row $(\varepsilon)$ of spines, group $\chi$ (near the longitudinal, but more basal and curved) with short spines, and group of tiny spines on basal part of internal margin (Pl. 2, Fig. 2). First endopodal segment with dense group of spines, second endopodal segment with spines, longer distally; third endopodal segment serrated on proximal third, plus two distal groups of spines (Pl. 1, Fig. 5). Longest seta on terminal endopodal segment and exopodal seta with spinules along outer margin (Pl. 1, Fig. 5). 


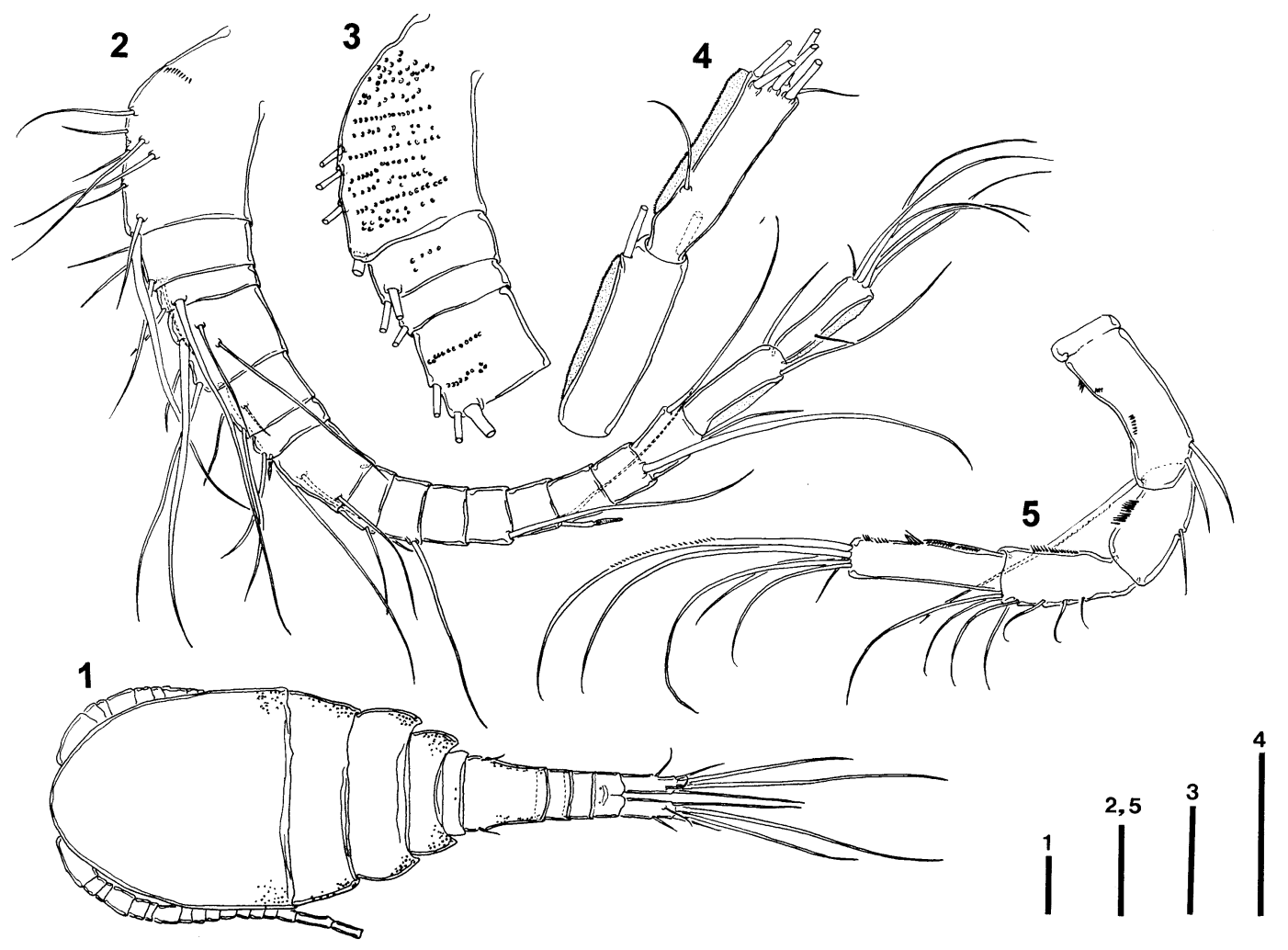

Plate 1. Figs 1-5. Mesocyclops evadomingoi $\mathrm{n}$. sp. female; 1. Habitus, dorsal view; 2. Antennule, inner view; 3. Antennule, segments I-IV outer view; 4. Antennule, segments XVI-XVII; 5. Antenna, caudal view. Scale bars $=100 \mu \mathrm{m}(1), 50 \mu \mathrm{m}(2-5)$.

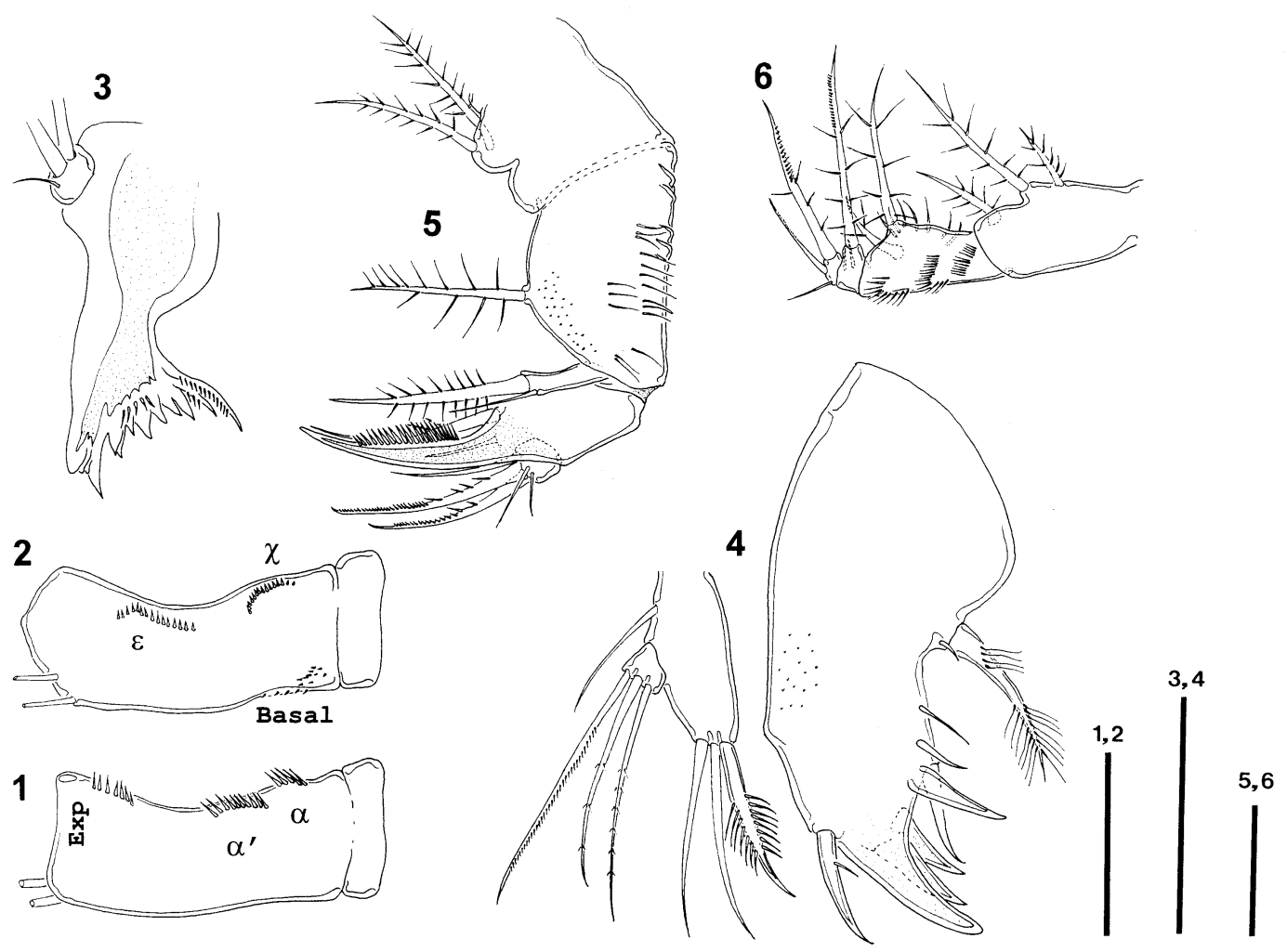

Plate 2. Figs 1-6. Mesocyclops evadomingoi n. sp. female; 1. Antenna, basis frontal view; 2. Antenna, basis caudal view; 3. Mandible; 4. Maxillule, caudal view; 5. Maxilla, caudal view; 6. Maxilliped, caudal view. Scale bars $=50 \mu \mathrm{m}$. 
Labrum. Distal margin toothed. Ventral surface with long hair-like setae, central ones longer than lateral ones. Plate with four pointed teeth in area where two groups of longer hair-like setae are medially conjoined (Pl. 9, Fig. 1).

Mandible. Gnathobase with 11 strongly chitinized teeth +5 small thin spines. Innermost margin with one spinulose seta, and one spinulose tooth. Palp with two long and one short setae (Pl. 6, Fig. 8). No spines next to palp (P1. 2, Fig. 3).

Maxillule. Praecoxal arthrite with three chitinized claws and one spiniform seta on frontal side. This seta with one or two spine-like setules near base. Inner margin with one biserially plumose seta, and five spiniform setae. Praecoxal surface bearing a group of scales next to palp (Pl. 2; Fig. 4; P1. 9, Fig. 2). Palp unarmed, with endopod (2 long smooth setae, plus one pinnate spine), distinct exopod (3 long, armed setae); and basoendopod with one smooth, external seta.

Maxilla. Praecoxa and coxa fused, forming a syncoxa; endite on praecoxa with two armed seta. Coxa with one long seta, distal coxal endite with apical seta furnished with spinules plus one short subdistal, smooth seta. A group of long, hair-like setae and group of scales on coxal caudal surface (Pl. 2, Fig. 5; Pl. 9, Fig. 3). Basis with one long seta with spines on proximal margin. Claw-like basal endite bearing around 20 long teeth on proximal margin: distalmost teeth stronger than proximal ones, and one very acute setae on frontal side. Endopod one-segmented, with two short distal setae; two long, armed, medial setae and one smooth, proximal seta (Pl. 2, Fig. 5).

Maxilliped. Syncoxa with three setae bearing spiniform setules. Basis with two setae, longer one 1.9 times length of shorter, both bearing spinules; with seven short setae on frontal surface. Three rows of small, acute spines, each with 16,15 , and 10 elements on caudal surface, distal and medial groups arranged in semicircular pattern, proximal one as a straight row (Pl. 2, Fig. 6). Endopod reduced, two-segmented, first segment with two basal spines plus one long seta, proximal part with long spinules, with short spinules distally. Second endopod with three setae increasing in size proximally, longest and medial setae with spinules distally (Pl. 2, Fig. 6).

Leg 1. Intercoxal sclerite naked on frontal and caudal surfaces, distal margin with two rounded, chitinized projections (Pl. 3, Fig. 1). Coxa with group of hair-like setae on external margin, plus group of long, acute spines near external margin, group of short, stout spines on proximal-external corner, and one long feathered seta on inner margin (2.1 times length of Enp 1) (Pl. 3, Fig. 2). Basis with long seta on external margin; internal margin hairy, with one delicate, naked seta 1.4 times longer than Enp 1 (Pl. 3, Fig. 2). Base of endopod with group of tiny spines. External margin of three endopodal and exopodal segments hairy, except distalmost margin of Enp 3, which is naked. Distal margin of first two endopodal segments with hair-like setae on caudal surface and one row of short spines on frontal surface (Pl. 3, Fig. 1).

Leg 2. Intercoxal sclerite naked on frontal and caudal side, distal margin with two rounded, low, chitinized projections (Pl. 3, Fig. 3). Coxa with hair-like seta on external margin, group of acute, long spines near external margin, group of short, stout spines on proximalexternal corner, single row of short spines on proximal margin, and one long feathered seta on inner margin (1.8 times length of Enp 1) (Pl. 3, Fig. 4). Basis with external hair-like setae, internal surface hairy (Pl. 3, Fig. 4). All endopodal segments with hair-like setae on external margin, except smooth distal margin of Enp 3 (Pl. 3, Fig. 3). First exopodal segment with two rows of external, short spines, row of short spines on distal margin (caudal view), row of long spines (frontal view) (Pl. 3, Fig. 5). Second segment with hair-like setae on external and internal margins, scales on caudal surface. Third segment with hair-like setae and spines on external margin, scales on caudal surface (P1. 3, Fig. 6).

Leg 3. Intercoxal sclerite naked on frontal and caudal surfaces, distal margin with two rounded, low, chitinized projections (Pl. 4, Fig. 1). Coxa with hair-like seta on external margin, group of strong, long spines near external margin, group of short, stout spines on proximal-external corner, and row of short spines on both proximal and distal margins. Inner margin with long, feathered seta (2.0 times length of Enp 1) (Pl. 4, Fig. 2). Inner margin of basis hairy (Pl. 4, Fig. 2). All endopodal segments hairy on external margin ( $\mathrm{Pl}$. 4, Fig. 1); ornamentation on exopodal segments as described for leg 2 (P1. 4, Fig. 3).

Leg 4. Intercoxal sclerite naked on frontal and caudal surfaces, distal margin with two rounded, very low, chitinized projections (Pl. 4, Fig. 4). Caudal surface of coxa with four groups of spines (two near external margin, one on distal-internal corner, and one on proximal margin), naked external margin, plus one large, feathered seta on inner margin (1.5 times length of enp 1). Coxal frontal surface with three groups of spines: two on distal margin, and one near external margin (Pl. 4, Fig. 5). Basis with one long seta on external margin, a group of dense, hair-like seta on inner margin (Pl. 4, Fig. 5). All endopodal and exopodal segments with external hair-like setae, except naked external margin of Exp 1 and distal margin of Exp 3 (Pl. 4, Fig. 4). Length ratio external spine/internal spine of Enp $3=1.3$. Length/width ratio Enp $3=2.5$. Insertion point of seta on external margin of Enp 3=56\% (Pl. 4, Fig. 6). 


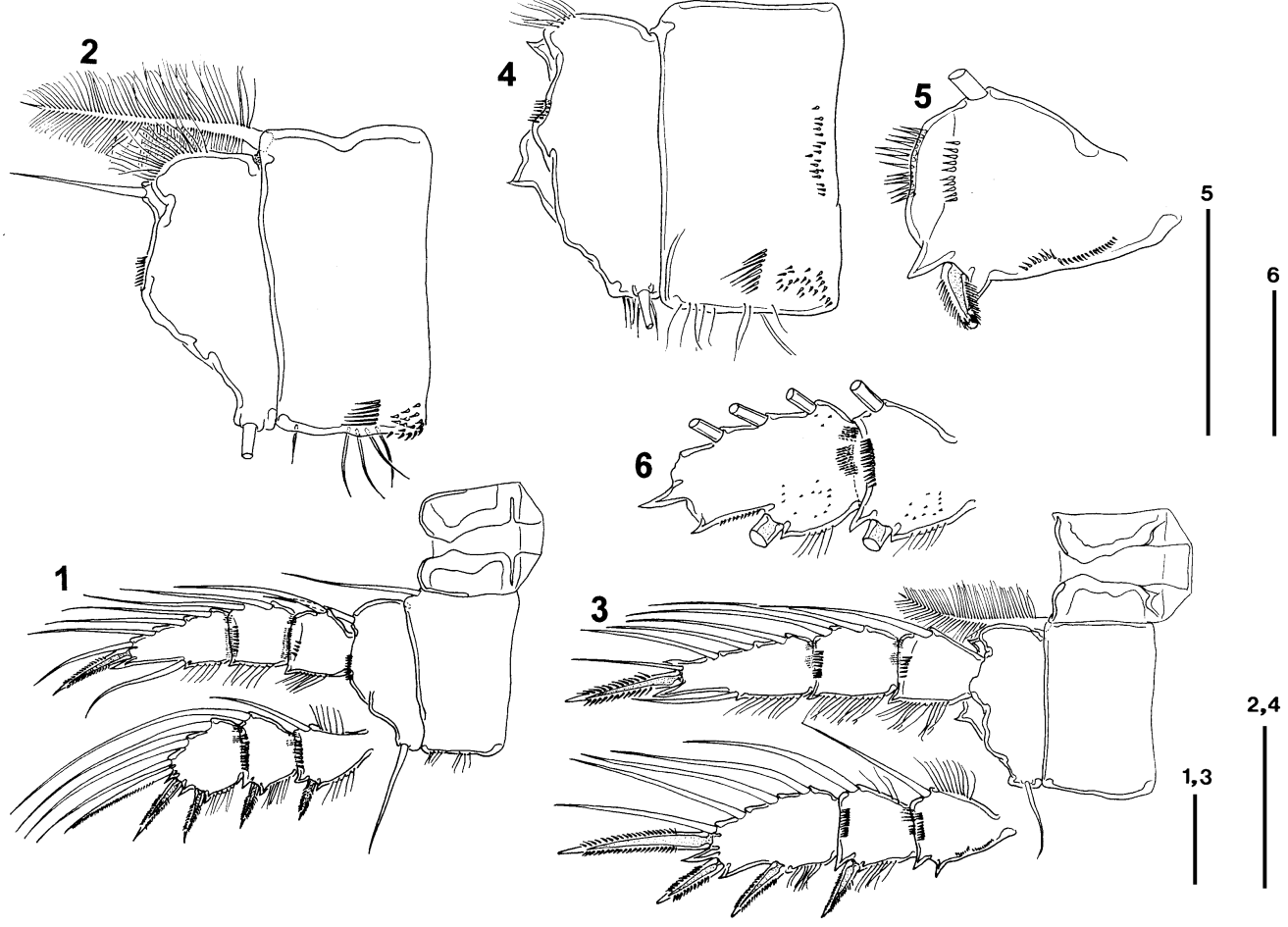

Plate 3. Figs 1-6. Mesocyclops evadomingoi n. sp. female; 1. First leg, caudal view; 2. First leg, coxa and basis caudal view; 3. Second leg, caudal view; 4. Second leg, coxa and basis caudal view; 5. Second leg, first exopodal segment; 6. Second leg, second and third exopodal segments. Scale bars $=50 \mu \mathrm{m}$.

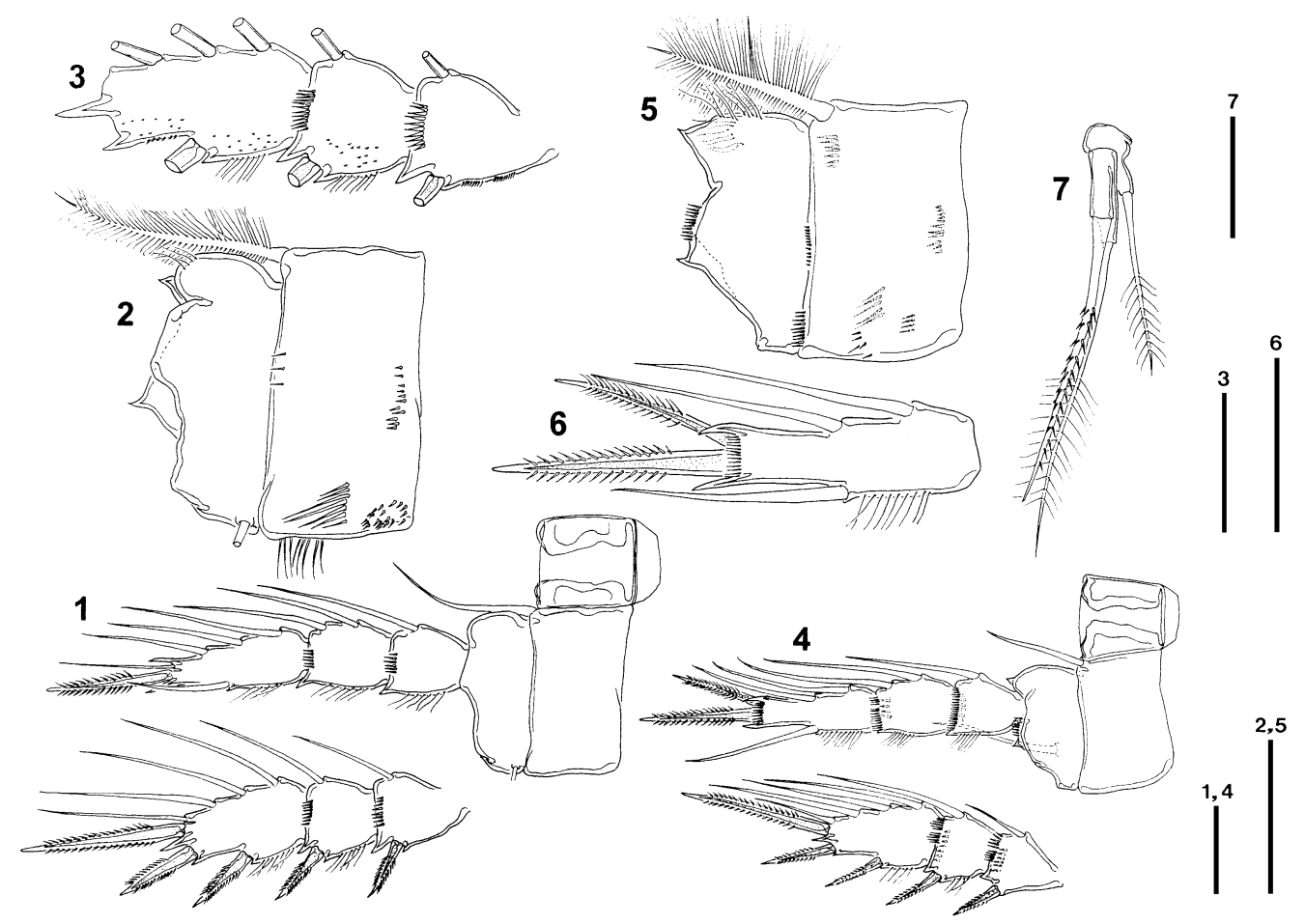

Plate 4. Figs 1-7. Mesocyclops evadomingoi $\mathrm{n}$. sp. female; 1 . Third leg, caudal view; 2 . Third leg, coxa and basis caudal view; 3. Third leg, exopodal segments; 4. Fourth leg, frontal view; 5. Fourth leg, coxa and basis frontal view; 6. Fourth leg, third endopodal segment; 7. Fifth leg. Scale bars $=50 \mu \mathrm{m}$. 
Leg 5. Medial spine on last segment of fifth leg with cluster of spines along margin, starting from proximal $1 / 3$. Length ratio of medial spine/apical seta of distal segment $=0.91$. Length ratio of medial spine distal segment/seta of proximal segment $=1.6(\mathrm{Pl} .4$, Fig. 7).

Leg 6. Long medial seta, plus one short spine; eight pores posterior to $\mathrm{Pl}$ (Pl. 9, Fig. 4).

Pediger 5. One row of acute spines and row of hair-like seta on external margin (on ventral surface) (P1. 5, Fig. 1). Dorsal surface naked (Pl. 5, Fig. 2).

Abdomen. Genital somite with scattered cuticular pits on ventral and dorsal surfaces (P1. 5, Figs 1-2). Ventral surface of second and third abdominal segments with pits arranged in transverse rows, hyaline fringe of each abdominal somite smooth (Pl. 5, Fig. 3). Length/width ratio of genital somite $=1.10-1.15$. Anterior margin of receptaculum seminis deeply convex. Lateral arms narrow. Posterior margin very narrow. Copulatory pore circular, channel associated to it like an inverted "J", directly connected to channels of posterior margin. Bursa elongated, sac-like (Pl. 5, Figs 1, 3). Anal somite ventral surface with numerous spines and scales on surface; and with row of spines on distal margin (Pl. 5, Fig. 4). Anal plate smooth, ramus with a few spines on distal margin, dorsal view (P1. 5, Fig. 5).

Furcal rami. Length/width ratio $=2.7$. Inner furcal margin hairy, ventral surface with hair-like setae and scales. Dorsal surface naked. No teeth at bases of antero-lateral and postero-lateral setae (Pl. 5, Figs 3-5).

\subsubsection{Description of male}

Total body length $=0.75 \pm 0.005 \mathrm{~mm}(\mathrm{n}=5)$, cephalotorax length $=0.47 \pm 0.01 \mathrm{~mm}(\mathrm{n}=5)$, abdomen length $=0.28 \pm 0.01 \mathrm{~mm}(\mathrm{n}=5)$. Body elongated, with pits on dorsal surface (P1. 6, Fig. 1).

Antennule. 16-segmented; armament per segment as follows: $8 \mathrm{~s}+3 \mathrm{ae}, 4 \mathrm{~s}, 2 \mathrm{~s}, 2 \mathrm{~s}+1 \mathrm{ae}, 1 \mathrm{~s}, 2 \mathrm{~s}, 1 \mathrm{~s}, 0 \mathrm{~s}, 1 \mathrm{ae}, 2 \mathrm{~s}$, $2 \mathrm{~s}, 1 \mathrm{~s}, 0 \mathrm{~s}, 1,1 \mathrm{~s}, 11 \mathrm{~s}+1$ ae. First geniculation between segments 7 and 8 , second one between segments 14 and 15. Segment I with proximal row of tiny spines. All segments with pits (Pl. 6, Fig. 2).

Antenna. Coxa (0 setae), basis (2 setae + exopod), and 3 -segmented endopod (1, 3, and 7 smooth setae). Pits on three endopodal segments, frontal surface (Pl. 6, Fig. 3). Basis frontal surface with same groups of spines present in female (Pl. 6, Fig. 4). Caudal surface of basis with longitudinal row $(\varepsilon)$, group $\chi$ (near the longitudinal one, but more basal) as in female, basal internal margin without spines (Pl. 6, Fig. 5). Ornamentation on margins of three endopodal segments as described for female (P1. 6, Fig. 3).

Labrum. Distal margin toothed. Ventral surface with long hair-like setae, central ones longer than lateral. A plate with four pointed teeth lies where two groups of longer hair-like setae are medially conjoined (P1. 9, Fig. $5)$.

Maxillule. Praecoxal arthrite with three chitinized claws and one spiniform seta on frontal surface. Inner margin as described for female. Differing from female, praecoxal surface smooth. Palp naked, with endopod (one smooth setae + one pinnate spine), separated exopod (3 long setae, differing from female, only proximalmost one with spinules); basoendopod with one smooth external seta (Pl. 7, Fig. 1).

Maxilla. Praecoxa and coxa fused forming a syncoxa; endite on praecoxa with two feathered setae. One long seta on coxa, distal coxal endite similar to female, with apical seta furnished with spinules, and one smooth, short, subdistal seta. Caudal surface of coxa and basis with pits, but no hair-like setae on coxa as in female. Basis with one long seta with spinules on both margins, one short seta on frontal surface. Claw-like basal endite with long, thin spines on proximal margin. Endopod one-segmented, with setae as described for female (P1. 7, Fig. 2).

Maxilliped. Syncoxa as in female. Basis with group of five short setae plus one long seta. Three spine groups on caudal surface, each with 9,10 , and 10 spines, two distalmost groups with curved pattern. Endopod as in female (Pl. 7, Fig. 3).

Leg 1. Intercoxal sclerite naked on frontal and caudal surfaces, distal margin with two rounded, chitinized projections. Ornamentation on coxa and basis as described for female. Feathered seta on coxa is 2.25 times length of Enp 1. Seta on internal margin of basis similar in length to Enp 1. External margin of all endopodal and exopodal segments smooth, except first exopodal segment with spines, and second exopodal segment with hair-like setae (P1. 7, Fig. 4).

Leg 2. Intercoxal sclerite smooth on frontal and caudal surfaces, distal margin with two rounded, low, chitinized projections. Coxa with two groups of spines: one near external margin and one on proximal margin and hair-like setae on external margin, plus one long feathered seta on inner margin (1.5 times length of Enp 1). Inner margin of basis hairy. All endopodal segments with hair-like setae on external margin, first exopodal segment with external row of spines. External margin of second exopodal segment nude, third segment with spines on distal margin ( $\mathrm{Pl}$. 7, Fig. 5).

Leg 3. Intercoxal sclerite naked on frontal and caudal surfaces, distal margin with two rounded, low, chitinized projections. Coxa ornamentation as described for female, except row of spines on distal margin, absent in males. Inner margin of basis hairy. All endopodal segments with hair-like setae on external margin, first exopodal segment with external row of spines. 


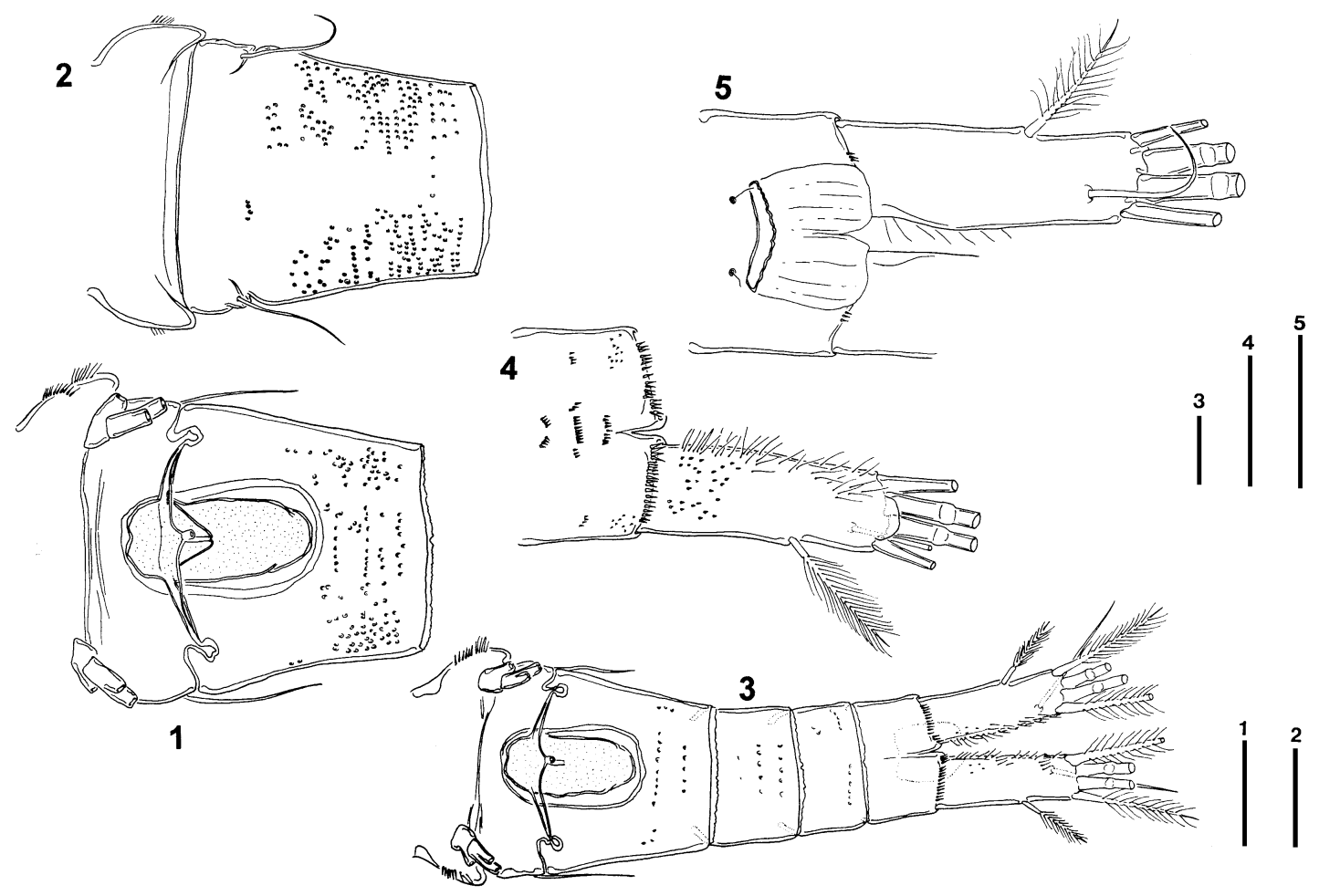

Plate 5. Figs 1-5. Mesocyclops evadomingoi n. sp. female; 1. Fifth pediger and genital somite, ventral view; 2 . Fifth pediger and genital somite, dorsal view; 3. Fifth pediger and abdomen, ventral view; 4. Anal somite and furcal rami, ventral view; 5. Anal somite and furcal rami, dorsal view. Scale bars $=50 \mu \mathrm{m}$.

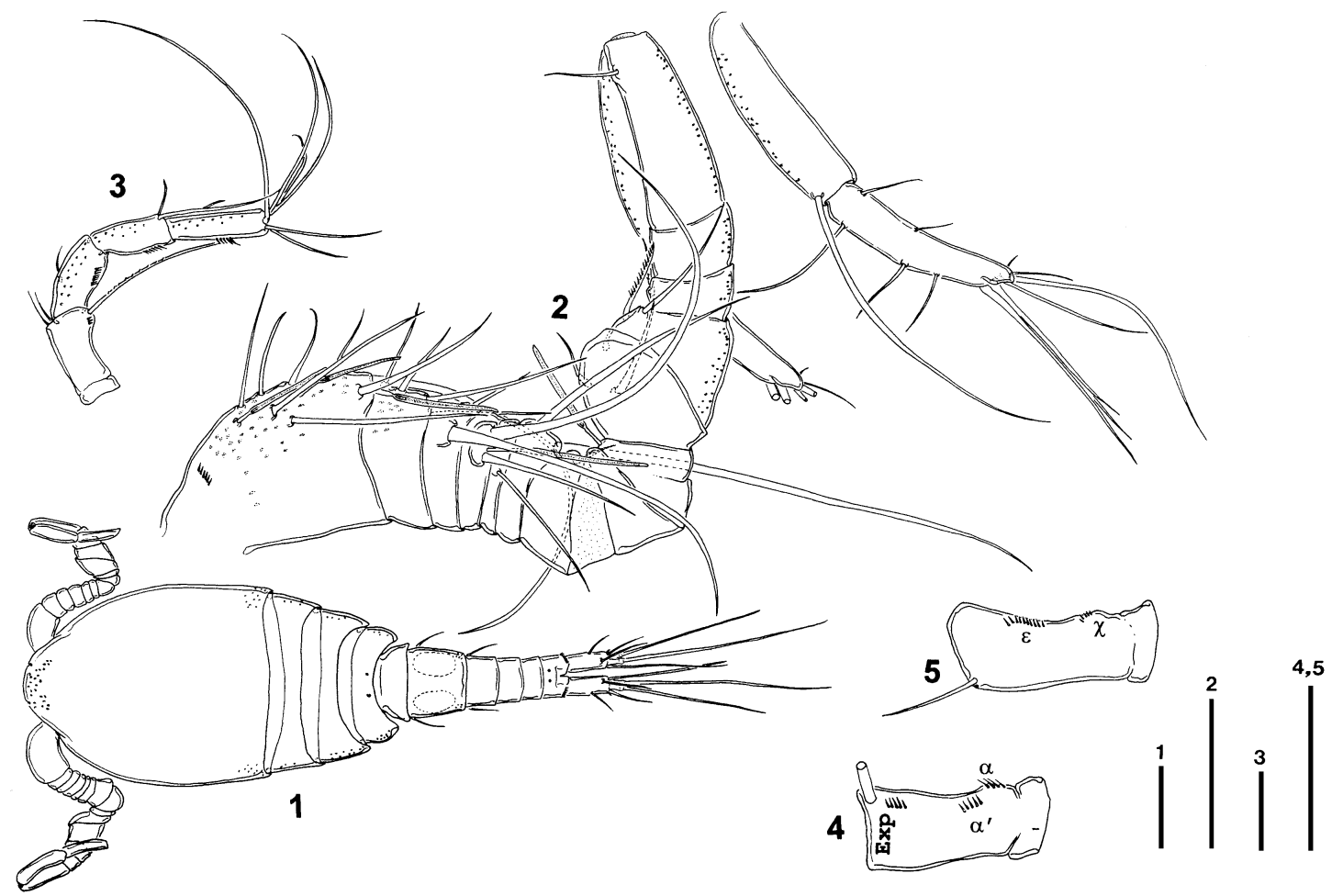

Plate 6. Figs 1-5. Mesocyclops evadomingoi n. sp. male; 1. Habitus, dorsal view; 2. Antennule, inner view, 3. Antenna, frontal view; 4. Antenna, basis frontal view; 5. Antenna, basis caudal view. Scale bars $=100 \mu \mathrm{m}(1), 50 \mu \mathrm{m}(2-5)$. 


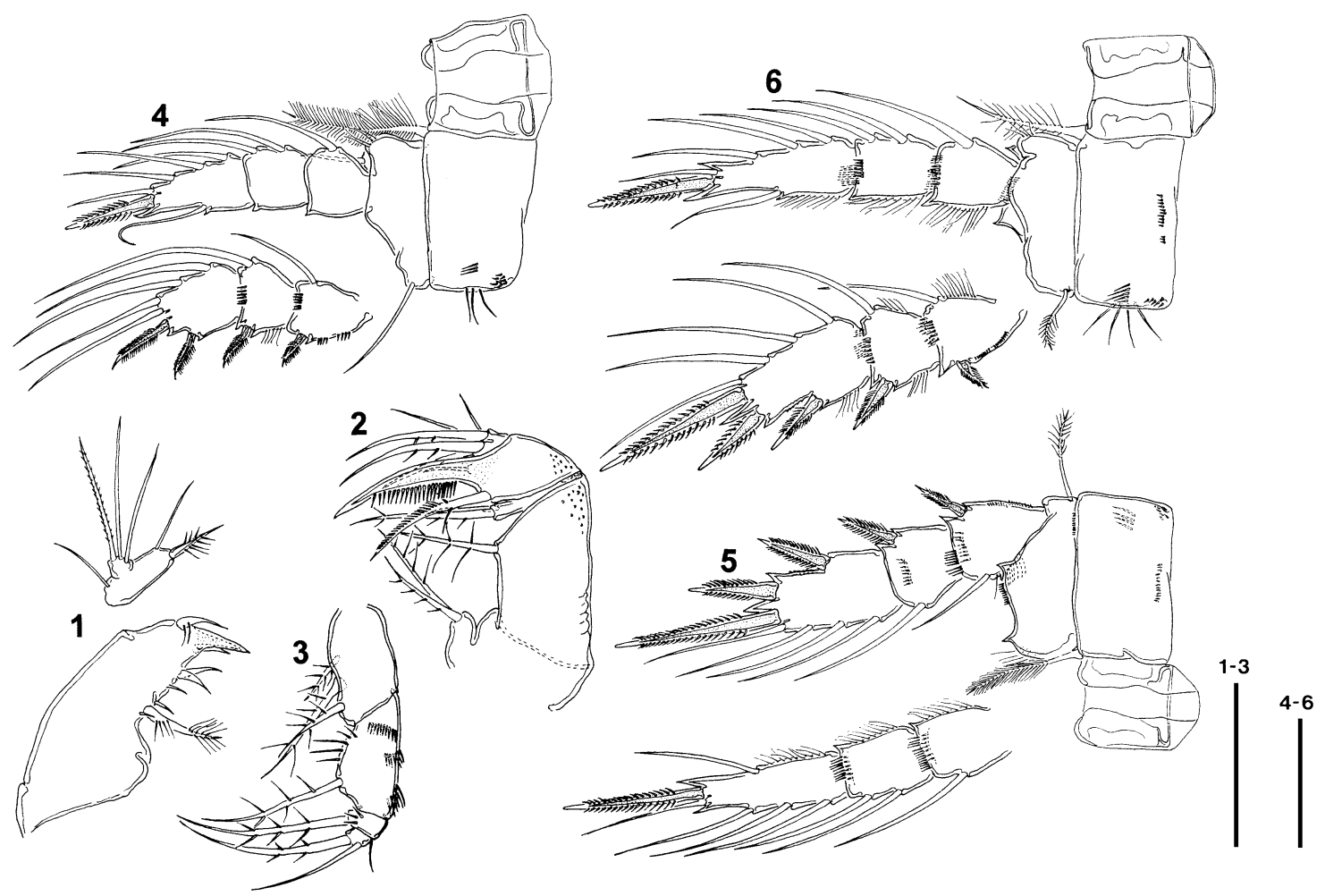

Plate 7. Figs 1-6. Mesocyclops evadomingoi n. sp. male; 1. Maxillule, caudal view; 2. Maxilla, caudal view; 3. Maxilliped, caudal view; 4. First leg, caudal view; 5. Second leg, frontal view; 6. Third leg, caudal view. Scale bars $=50 \mu \mathrm{m}$.

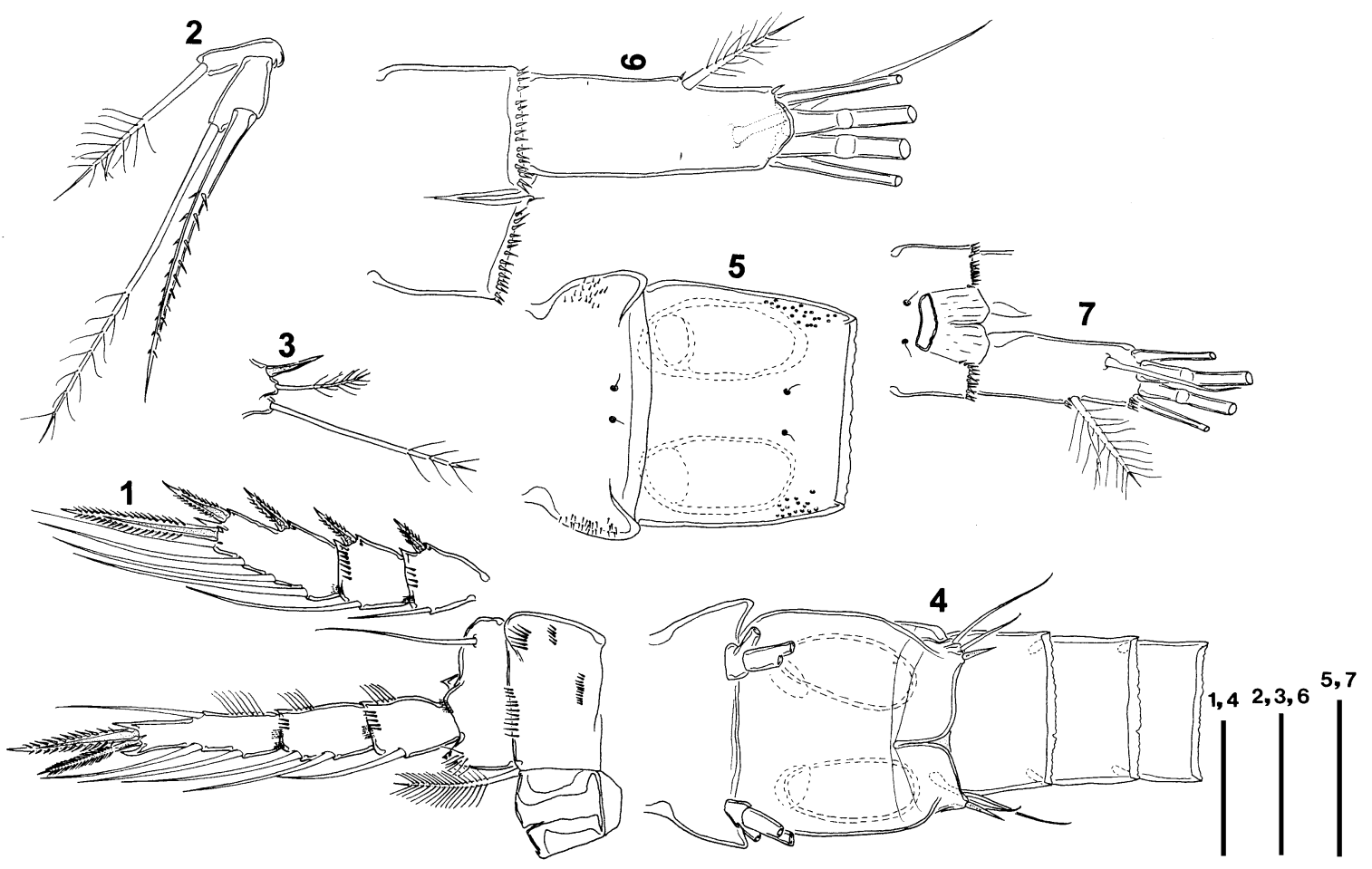

Plate 8. Figs 1-7. Mesocyclops evadomingoi n. sp. male; 1. Fourth leg, caudal view; 2. Fifth leg; 3. Sixth leg, 4. Fifth pediger, genital somite, and three abdominal segments, ventral view; $\mathbf{5}$. Fifth pediger and genital somite, dorsal view; 6 . Anal somite and furcal rami, ventral view; 7. Anal somite and furcal rami, dorsal view. Scale bars $=50 \mu \mathrm{m}$. 
Tab. 1. Comparison among four American species of Mesocyclops with convex anterior margin of the seminal receptacle.

\begin{tabular}{|c|c|c|c|c|}
\hline & M. evadomingoi & M. pseudomeridianus & M. meridianus & M. annulatus \\
\hline $\begin{array}{l}\text { Antennule cuticular } \\
\text { ornamentation, external } \\
\text { surface }\end{array}$ & $\begin{array}{l}\text { Pits on segments I, II, and } \\
\text { IV }\end{array}$ & No ornamentation & No ornamentation & Pits on segments I and IV \\
\hline $\begin{array}{l}\text { Antennule segment XVII, } \\
\text { hyaline membrane }\end{array}$ & $\begin{array}{l}\text { Without distal notches, } \\
\text { straight, lightly serrated }\end{array}$ & Three deep distal notches & Two deep distal notches & One deep distal notch \\
\hline Maxillule, caudal surface & Tiny scales next to palp & Hair-like setae & Strong, acute spines & Naked \\
\hline $\begin{array}{l}\text { Maxilla, caudal surface of } \\
\text { coxa }\end{array}$ & $\begin{array}{l}\text { One group of tiny spines } \\
\text { next to endite plus hair- } \\
\text { like setae }\end{array}$ & Groups of acute spines & One row of acute spines & Not observed \\
\hline $\begin{array}{l}\text { First leg, basipodal medial } \\
\text { seta }\end{array}$ & Weak, smooth & Strong, setulated & Strong, setulated & Strong, setulated \\
\hline $\begin{array}{l}\text { Fifth pediger (ventral } \\
\text { ornamentation) }\end{array}$ & $\begin{array}{l}\text { One row of spines, and } \\
\text { row of hair-like setae }\end{array}$ & One group of spines & One group of spines & $\begin{array}{l}\text { One group of hair-like } \\
\text { setae }\end{array}$ \\
\hline $\begin{array}{l}\text { Genital somite cuticular } \\
\text { ornamentation }\end{array}$ & $\begin{array}{l}\text { Pits on dorsal and ventral } \\
\text { surfaces }\end{array}$ & Pits absent & Pits absent & Pits absent \\
\hline $\begin{array}{l}\text { Seminal receptacle, } \\
\text { anterior margin }\end{array}$ & Deeply convex & $\begin{array}{l}\text { Weakly convex, almost } \\
\text { straight }\end{array}$ & Convex & $\begin{array}{l}\text { Weakly convex, almost } \\
\text { straight }\end{array}$ \\
\hline
\end{tabular}

Second exopodal segment with hair-like setae. Third segment with hair-like setae on proximal margin and spines on distal (Pl. 7, Fig. 6).

Leg 4. Intercoxal sclerite naked on frontal and caudal surfaces, distal margin smooth, rounded. Ornamentation of coxal surface and basis as described for the female. All endopodal segments with external hair-like setae. All exopodal segments naked, except distal margin of third exopodal segment, with row of small protuberances. Length ratio of external spine/internal spine of Enp 3=1.2. Length/width ratio of Enp 3=3.3. Insertion point of seta on external margin of Enp $3=55 \%$ (Pl. 8, Fig. 1).

Leg 5. Medial spine on last segment of fifth leg very similar to female. Length ratio of medial spine/apical seta of distal segment $=0.87$. Length ratio of medial spine on distal segment/seta on proximal segment $=1.5$ (P1. 8, Fig. 2).

Leg 6. With three setae increasing in length distally. Distalmost seta 3.5 times longer than proximalmost (spine-like), 2.2 times longer than medial seta ( $\mathrm{Pl}$. 8, Fig. 3).

Pediger 5. No spines or hairs on ventral surface of external margin (Pl. 8, Fig. 4). Hair-like setae on dorsal surface (Pl. 8, Fig. 5).

Abdomen. Ventral surface of genital somite naked (Pl. 8, Fig. 4); pits on dorsal surface (Pl. 8, Fig. 5). Length $/$ width ratio of genital somite $=0.9$. Hyaline fringe of each abdominal segment smooth (Pl. 8, Fig. 4). Distal margin of anal somite with continuous row of spines in dorsal and ventral views (Pl. 8, Figs 6-7); anal Pl. smooth (Pl. 8, Fig. 7).

Furca. Length $/$ width ratio $=2.5$. Spines on insertion of lateral seta, and on postero-lateral corner surrounding external seta (Pl. 8, Figs 6-7). Scales on ventral and dorsal surfaces (Pl. 9, Fig. 6).

\subsection{Remarks}

The new species can be distinguished from all the other known species of Mesocyclops by the combination of several characters. These include mainly the shape of the hyaline membrane, the ornamentation of both maxillule and maxilla, the ornamentation of the fourth leg, the shape of the genital receptacle, and the ornamentation of the furcal rami.

The hyaline membrane of the last antennular segment shows different shapes throughout the genus, it has commonly one or two notches distally or have a strongly serrate margin (i.e. M. brasilianus, $M$. meridianus, M. aspericornis Daday, 1906). It is slightly serrated and straight in the new species, and no other known American species shows this kind of membrane.

The small cuticular scales on the caudal surface of the maxillule in M. evadomingoi is a relevant feature mainly because they are not on the palp. This is the only species known to show this kind of scale ornamentations in a non-palp structure, other species show hairlike setules or large spines on this surface (see Tab. 1). On the other hand, van de Velde (1984) pointed out the importance of the ornamentation on the maxillular palp in distinguishing different African species (i. e. $M$. ogunnus Onabamiro, 1957, and M. salinus Onabamiro, 1957). Apparently, only the American species show cuticular ornamentations on the caudal surface of the maxillule (see Tab. 1). Therefore, this character (when present), can be a useful feature to separate American species as well.

The ornamentation of the maxilla, with hair-like setae on the caudal surface, is also a relevant distinguishing character in the new species. A different ornamentation pattern has been observed in some other American species such as M. pseudomeridianus and M. meridianus (see Tab. 1), all with small spines only. 

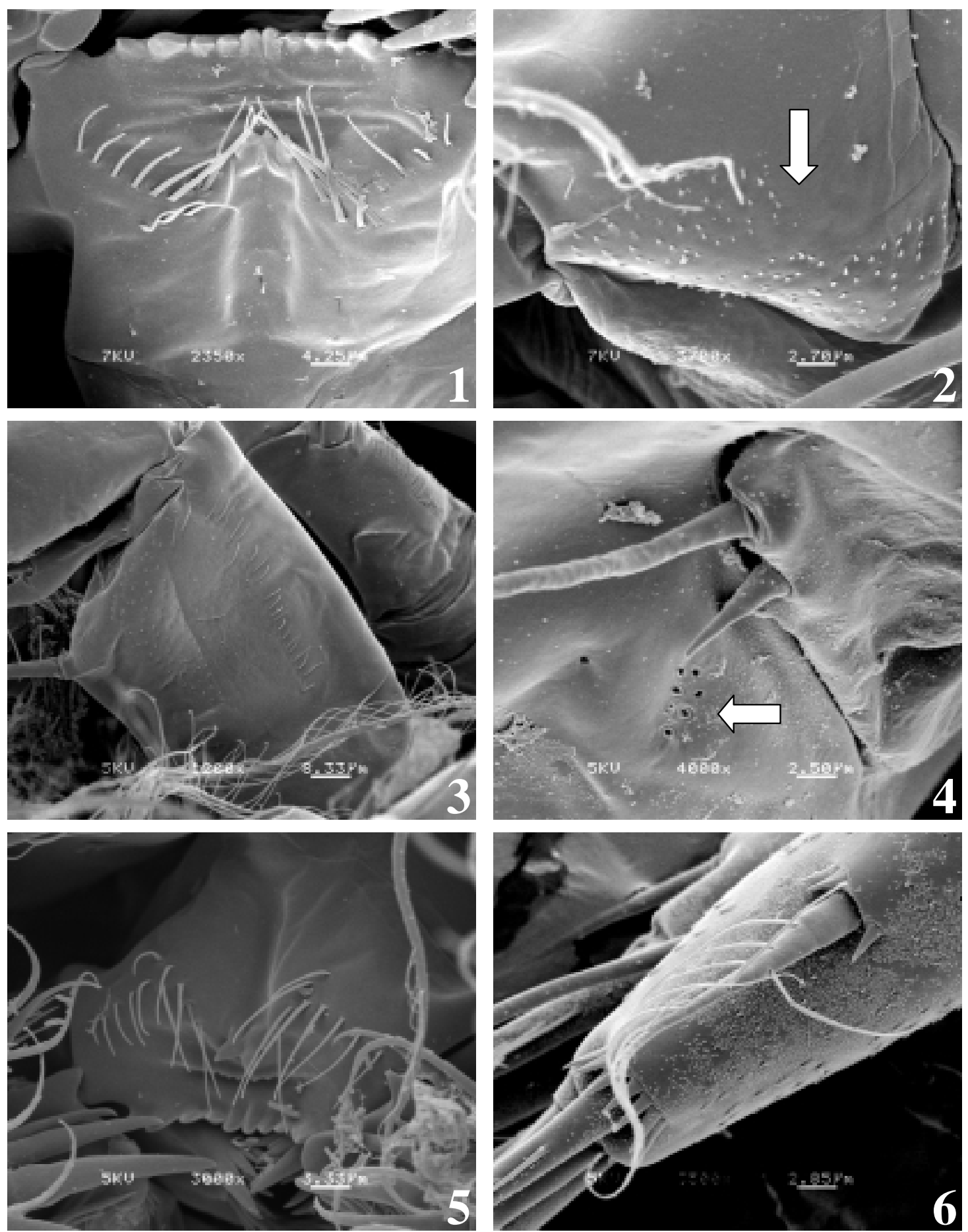

Plate 9. Figs 1-6. Mesocyclops evadomingoi n. sp. female; 1. Labrum, ventral view; 2. Maxillule, detail of the triangular scales on caudal surface (arrowed); 3. Maxilla, detail of coxa, caudal view; 4. Sixth leg and cuticular pores (arrowed); Mesocyclops evadomingoi n. sp. male; 5. Labrum, ventral view; 6. Furcal rami, lateral view. 
The fourth legs of the new species has a relatively simple ornamentation on the caudal surface of the coxa, when compared with the complex patterns present in the morphologically similar $M$. meridianus. Moreover, in $M$. annulatus this pattern includes very large, distinctive spines in the same surface.

Some features present in the mouthparts of the female M. evadomingoi (i.e. the group of basal spines on the antennal basis, the spines and hair-like setae on the maxillar coxa, and the tiny spines on the maxillule) are absent in the male. However, both sexes share other important characters, such as the ornamentation pattern of the coxa and basis of the first to fourth legs. Taking into account that the spine pattern on the caudal surface of the coxa (especially in the fourth leg), is considered as a species-specific stable feature (Holynska 2000a), it is clear that the features of the males could be as valuable as those of the females to separate the species.

The seminal receptacle of $M$. evadomingoi resembles mostly that of $M$. pseudomeridianus Defaye \& Dussart 1988 in several features such as the convex anterior margin, the sac-like bursa, and the lateral arms reduced to canals ending in the genital antra. However, in the new species the canal connected to the copulatory pore has the shape of an inverted "J", and both anterior and posterior canals are joined almost at the level of the seminal receptacle (appearing as a single canal). Conversely, in $M$. pseudomeridianus the canal connected to the copulatory pore is clearly straight, and the anterior and posterior canals are completely separated (the two canals are directed toward both sides of the genital somite) (Defaye \& Dussart 1988; Holynska 2000b). Additional morphological differences between M. evadomingoi and other species with a convex anterior margin of the seminal receptacle are presented comparatively in table 1.

The presence of cuticular scales on the ventral surface of the furcal rami appears to be an additional taxonomic character useful to separate this new species from all other known American Mesocyclops. In these other species (M. brasilianus, M. venezolanus Dussart, 1987, M. varius Dussart, 1987), the ornamentation of the furcal rami includes mainly setules along the internal margin or small hair-like projections on the surface (see Dussart, 1987), but no scales.

\section{DISCUSSION}

Several American species of Mesocyclops (i.e., M. pseudomeridianus, M. meridianus, and $M$. annulatus) show a group of spines next to the implantation of the exopodal seta of the antenna. This feature, as well as the convex anterior margin of the seminal receptacle, and the very thin channels ending in the genital antra (sensu Holynska 2000b), represent morphological characters shared with some Australasian and African species (i.e., M. paludosus Lindberg, 1956, M. rarus Kiefer, 1981, M. darwini Dussart \& Fernando, 1988, and M. daya- korum Holynska, 2000b). The most remarkable difference between these American species and the Old World ones, is that the distal margin of the intercoxal sclerite of the fourth leg is not projected in the American group, whereas it bears large, acute outgrowths in the Australasian and African forms.

This is the $11^{\text {th }}$ species of Mesocyclops known from Mexico, and the third new species described upon Mexican material, after M. yutsil Reid, 1996 and M. chaci Fiers, 1996, found in the Yucatan Peninsula (Fiers et al. 1996). These two species seem to have a restricted distribution (Fiers et al. 1996; Suárez-Morales et al. 1996). Conversely, the new species is expected to have a wider distribution. This could be related to the affinity of the Tabasco fauna (Gutiérrez-Aguirre \& SuárezMorales 2001b) with the Caribbean and South American copepod faunas. Furthermore, it is probable that some of the regional records of $M$. meridianus (mainly in South America) could be eventually assigned to $M$. evadomingoi.

\section{ACKNOWLEDGMENTS}

We thank A. Cervantes-Martínez, C. Quintal-Lizama, A. García-Morales, M. Elías-Gutiérrez, I. Castellanos-Osorio, and C. Curiel-Mondragón ECOSURChetumal, for collecting zooplankton samples at Tabasco and for making them available to us. SEM photographs were taken by Guadalupe Nieto López, ECOSUR-Tapachula. Some analyzed specimens were a gift by Marcos da Silva. Janet W. Reid, National Museum of Natural History at Washington, D.C., kindly revised the specimens and made relevant and useful comments to build this contribution. Danielle Defaye, Muséum National d'Histoire Naturelle, Paris, kindly made types and museum's specimens available to us. This work is part of the postgraduate project by the first author to survey the neotropical and Mexican Mesocyclops, supported by CONACYT (32483-T-1999).

\section{REFERENCES}

Defaye, D. \& B.H. Dussart. 1988. Compléments à la faune des Crustacés Copépodes des eaux intérieures de Guyane française. Rev. Hydrobiol. trop., 21: 109-125.

Dussart, B.H. 1987. Sur quelques Mesocyclops (Crustacea, Copepoda) d'Amérique du Sud. Amazoniana, 10: 149-161.

Dussart, B.H \& C.H. Fernando. 1988. Sur quelques Mesocyclops (Crustacea, Copepoda). Hydrobiologia, 157: 241264.

Fiers, F., J.W. Reid, T.M. Iliffe \& E. Suárez-Morales. 1996. New hypogean cyclopoid copepods (Crustacea) from the Yucatán Peninsula, Mexico. Contributions to Zoology, 66: 65-102.

Gutiérrez-Aguirre, M.A. \& E. Suárez-Morales. 2001a. Distribution and taxonomy of the tropical American Mesocyclops G. O. Sars, 1914. Crustaceana, 74: 477-487.

Gutiérrez-Aguirre M. A \& E. Suárez-Morales. 2001b. Diversity and distribution of freshwater copepods (Crustacea) in Southeastern Mexico. Biodiversity and Conservation, 10: 659-672.

Holynska, M. 2000a. Is the spinule pattern on the leg 4 coxopodite a tactile signal in the specific mate recognition 
system of Mesocyclops (Copepoda, Cyclopoidae)? Hydrobiologia, 417: 11-24.

Holynska, M. 2000b. Revision of the Australasian species of the genus Mesocyclops Sars, 1914 (Copepoda: Cyclopidae). Annales Zoologici, 50: 363-447.

Suárez-Morales, E., J.W. Reid, T.M. Iliffe \& F. Fiers. 1996. Catálogo de los copépodos (Crustacea) continentales de la Península de Yucatán, México. Comisión Nacional para el Conocimiento y Uso de la Biodiversidad (CONABIO) El Colegio de la Frontera Sur (ECOSUR). Chetumal: 296 pp.

Received: March 2001

Accepted: April 2001
Suárez-Morales, E. \& J.W. Reid. 1998. An updated list of the free-living freshwater copepods (Crustacea) of Mexico. The Southwestern Naturalist, 43: 256-265.

van de Velde, I. 1984. Revision of the African species of the genus Mesocyclops Sars, 1914 (Copepoda: Cyclopidae). Hydrobiologia, 109: 3-66.

van de Velde, I. 1987. New Mesocyclops species (Copepoda, Cyclopidae) from Papua New Guinea. Biologie, 57: 149162. 